\title{
CBS VE AHS KULLANILARAK DOĞAL ÇEVRE BİLEŞENLERİ AÇISINDAN KENTSEL MEKÂNIN YERLEŞIME UYGUNLUK ANALIZİNE BİR ÖRNEK: ANTAKYA (HATAY)
}

The Analysis of Habitability of Urban Spaces In Terms of Natural Environmental Components By Means of GIS and AHP: The Case of Antakya (Hatay)

\begin{abstract}
Yrd. Doç. Dr. Emre ÖZŞAHIN*
Arş. Gör. Çağlar Kıvanç KAYMAZ ${ }^{* *}$

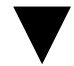

Özet

Son yıllarda dünya genelinde hızl bir şekilde gelişen kentler, doğal ortamda birçok probleminde ortaya çıkmasına neden olmuştur. Ortaya çıkan bu problemlerin çözümü için kent alanlarında uygun yer seçimi çalışmalarının yapılması gerekmektedir. Bu bă̆lamda özellikle Coğrafi Bilgi Sistemleri (CBS) tekniklerinden yararlanılarak oldukça ciddi çalışmalar gerçekleştirilmektedir. Bu çalışmada Hatay ilinin merkezini oluşturan Antakya kentinin doğal çevre bileşenlerinin yerleşime uygunluk açısından analizi yapılmıştır. Çalışmada materyal olarak 1/25.000 ölçek oranı esas alınarak çeşitli tematik haritalardan yararlanılmıştır. Çalışmanın analiz ve haritalama aşaması CBS yazılımlarından ArcGIS/ArcMap 10.1 paket programı kullanılarak gerçekleştirilmiştir. Yöntem olarak ise çok kriterli karar verme yöntemlerinden biri olan Analitik Hiyerarşi Süreci (AHS)'den yararlanılmıştır. Çalışma sonunda Antakya kentinin yarısından fazlasının yerleşmeye az uygun sahalardan oluştuğu tespit edilmiştir. Yerleşmeye uygunsuz alanlar, başta Asi Nehri olmak üzere akarsu vadileri ile fay hatlarına yakın konumda bulunan sahalardır. Kentin yakın gelecekte genişleyeceği mücavir alan sınırları içerisinde bazı riskli alanlar bulunmasına rağmen, en güvenilir alanlar bu bölgededir. Nihai aşamada ise kentlerin sürdürülebilir bakımından planlanması için doğal çevre bileşenlerini dikkate alan çalışmaların yapılmasına ihtiyaç vardır. Bu tarz çalışmalarda CBS'ye dayalı yöntemlerin kullanılması sağlıklı ve kullanılabilir sonuçlar üretilmesi bakımından oldukça mühimdir. Bu yöntemlerin benzer alanlarda da uygulanabilir olması bakımından tercih edilebileceği anlaşılmıştır.
\end{abstract}

\footnotetext{
* Namık Kemal Üniversitesi Fen-Edebiyat Fakültesi Coğrafya Bölümü, Tekirdağ.

E-mail: eozsahin@nku.edu.tr

** Atatürk Üniversitesi Edebiyat Fakültesi Coğrafya Bölümü, Erzurum.

E-mail: ckkaymaz@gmail.com
} 
CBS ve AHS Kullanılarak Doğal Çevre Bileşenleri Açısından Kentsel Mekânın Yerleşime Uygunluk Analizine Bir Örnek: Antakya (Hatay)

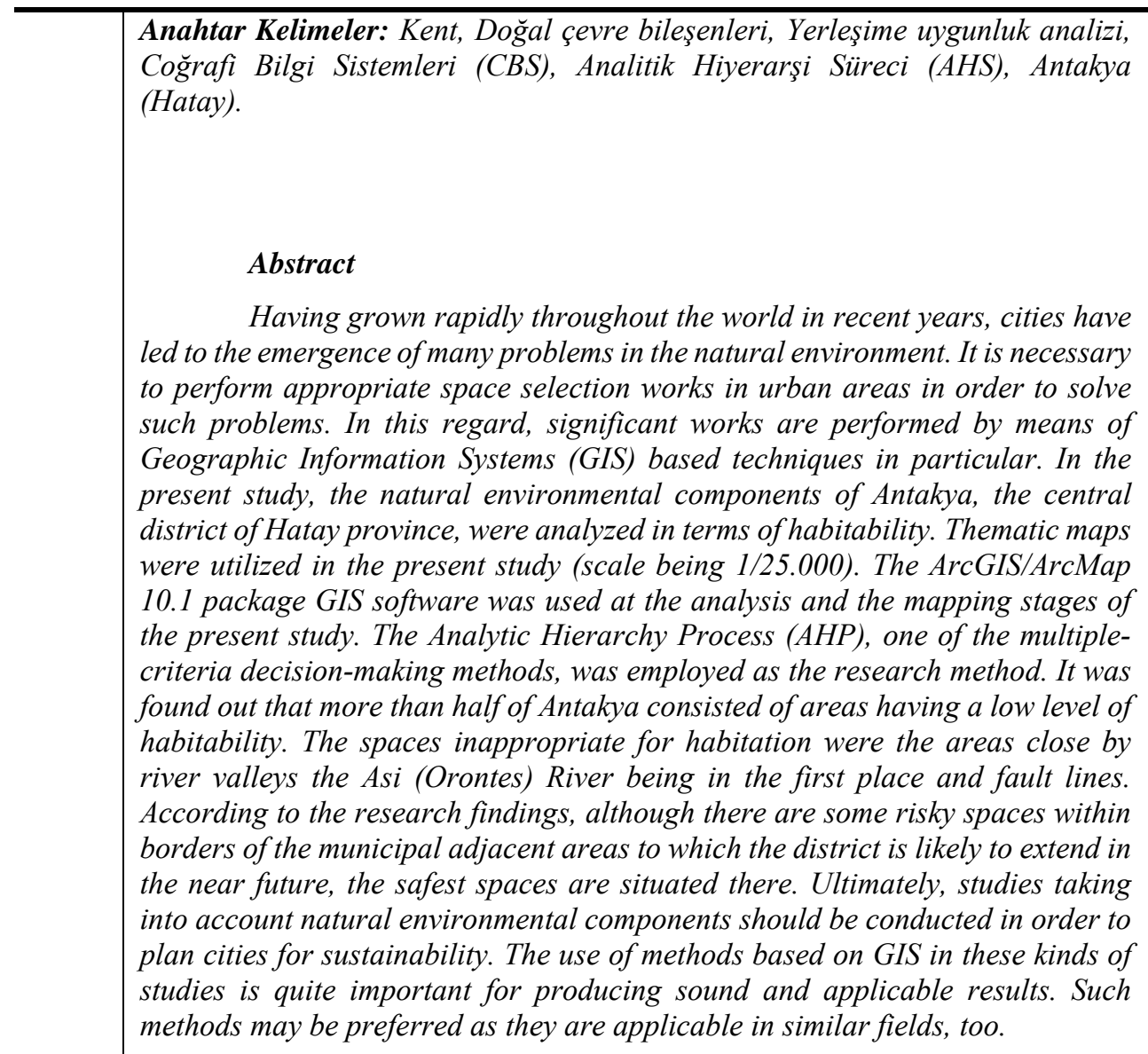

Keywords: Urban, Natural Environmental Components, settlement suitability analysis, Geographic Information Systems (GIS), Analytic Hierarchy Process (AHS), Antakya (Hatay). 
The Analysis of Habitability of Urban Spaces In Terms of Natural Environmental Components By Means of GIS and AHP: The Case of Antakya (Hatay)

\section{GİRIŞ}

Sanayi devrimiyle birlikte hız kazanan kentleşme, son yıllarda dünya nüfusunun hızla artmasıyla birlikte küresel anlamda bir boyut kazanmıştır (Berry, 1990: 103; Çetin, 2012a: 233). Günümüzde dünya nüfusunun yaklaşık yarısı kentlerde yaşamaktadır (Demographia, 2012: 1; Döker, 2012: 122). Zira dünya kent nüfusu toplam nüfustan daha hızlı bir şekilde artmakta olup (Brown vd., 2005: 1), 2030 yılına kadar dünya nüfusunun \% 60'tan fazlasının kentlerde yaşayacağı tahmin edilmektedir (Paul ve Meyer, 2001: 333; Erdem ve Serdar Kaya, 2013: 390). Dünya genelinde kentleşme hareketinde yaşanan bu dramatik değişimler Türkiye'de de belirgin bir şekilde kendini hissettirmiştir. Türkiye'de 1950'lerden sonra belirginleşmeye başlayan kentleşme günümüze doğru hızlı bir ivme göstermiştir (Aydın, 2011: 136). Elverişli coğrafi şartları ve geçmişten gelen yoğun nüfusyerleşme özellikleriyle birlikte, bilhassa 1950'lerden sonra başlayan tarım ve sanayi hamleleri sonucunda kentleşme sürecini derin bir şekilde hisseden yerlerden birisi de Hatay'dır. Nitekim son 70 yıllık süreçte ilin toplam nüfusu yaklaşık 6 kat artarken, kentli nüfus 22.5 kat büyümüştür (Çetin, 2012a: 235).

Genel olarak hem Dünya'da, hem Türkiye'de, hem de Hatay'da yaşanan bu hızlı kentleşme, doğal ortamda birçok probleminde ortaya çıkmasına neden olmuştur. Gerçekten de gerek ulusal, gerekse uluslararası alanda yapılan çalışmalarda kentleşmenin doğal ortam üzerine biyolojik (Hynes, 1960; House vd., 1993; Ellis ve Marsalek, 1996; Suren, 2000), fiziksel ve kimyasal (Klein 1979; Heany ve Huber 1984), hidrolojik (Butler ve Davies, 2000; Baer ve Pringle, 2000), ekolojik (Porcella ve Sorenson, 1980; Duda vd., 1982) olmak üzere birçok olumsuz sonuçlar doğurduğu tespit edilmiştir. Bilhassa Antakya'daki kentleşmeyi konu alan coğrafi çalışmalarda plansız kentleşmenin birçok doğal çevre problemlerine neden olduğu çok sık bir şekilde vurgulanmıştır (Korkmaz, 2006; Çetin, 2012a; 2012b; Özşahin, 2010; Değerliyurt, 2013; Özşahin ve Kaymaz, 2013a; Özşahin ve Değerliyurt, 2013).

Son yıllarda plansız kentleşmenin çözümlenmesi adına kent alanlarında uygun yer seçimi çalışmalarının yapılmasına dikkat çekilmiştir (Bayar, 2005: 21). Böylece daha sağlıklı planlamalar yapılacak, doğru kararlar alınabilecek ve alandan en yüksek verimle faydalanabilecektir. Bu bağlamda özellikle Coğrafi Bilgi Sistemleri (CBS) tekniklerinden yararlanılarak oldukça ciddi çalışmalar gerçekleştirilmiştir. Dai vd. (2001) CBS kullanarak Çin'in Lanzhou kentinin doğal çevresinin sürdürülebilirlik haritasını üretmişlerdir. Lee vd. (2003), Lee ve Sambath (2006) ve Angillieri (2010) kent ekolojisine zarar veren heyelan olaylarını CBS tekniklerinden yararlanarak analiz etmişler ve haritalamışlardır. Uy ve Nakagoshi (2008) CBS'ye dayalı yaklaşımlarla kentsel çevrenin sürdürülebilirlik analizini yapmışlardır. Park vd. (2011) Güney Kore örneğinde CBS'ye dayalı tekniklerle kentsel sürdürülebilir arazi indeksini tespit etmişler ve haritalandırmışlardır.

$\mathrm{Bu}$ çalışmada, Hatay ilinin merkezini oluşturan Antakya kentinin doğal çevre bileşenlerinin yerleşime uygunluk açısından değerlendirilmesi amaçlanmıştır. $\mathrm{Bu}$ amaç kapsamında Analitik Hiyerarşi Süreci (AHS) yönteminden yararlanılarak CBS destekli bir analiz gerçekleştirilmiştir. 2012 TUIK ADNKS verilerine göre 216.960 kişi ile km²'ye 10138 kişinin düştüğü yoğun nüfuslu bir kent alanındaki insan mekân ilişkisine dikkat çekmek ve 2013 yılında büyükşehir olan kentin sürdürülebilir planlanmasına katkı sağlamak için 
CBS ve AHS Kullanılarak Doğal Çevre Bileşenleri Açısından Kentsel Mekânın Yerleşime Uygunluk Analizine Bir Örnek: Antakya (Hatay)

çalışma alanı olarak Antakya kenti seçilmiştir. Çalışmanın önemi, öncelikle Antakya için doğal ortam koşullarının yerleşime uygunluk açısından değerlendirilmesinin yapıldığı öncü bir çalışma olmasından kaynaklanmaktadır. Bilhassa bu yayın, daha çok planlamalar için önem taşımaktadır. Ayrıca elde edilen bulgular ve sonuçlar, konu hakkında kuramsal çalışmalara ve hipotezlerin geliştirilmesine yardımcı olabileceği gibi, bu konuda çalışacak bilim insanlarına da bir kaynak teşkil edebilecektir.

\section{2. İNCELEME ALANININ KONUMU VE GENEL ÖZELLİKLERİ}

Antakya şehri, Doğu Akdeniz havzasında ve Türkiye'nin güneyinde $36^{\circ} 05^{\prime} 22.503^{\prime \prime}$ - 36 $16^{\circ} 39.342^{\prime \prime}$ doğu boylamları ile $36^{\circ} 15^{\prime} 42.553^{\prime \prime}$ - 36 10' 29.71" kuzey enlemleri (UTM Zon $37 \mathrm{~K}$ - WGS84) arasında yer almaktadır. Türkiye mülki idari sistemine göre Hatay ilinin merkez ilçesi Antakya’nın kent merkezidir. Kent alanı mücavir alan sınırı dâhil olmak üzere $21.4 \mathrm{~km}^{2}$ 'dir (Şekil 1;2).

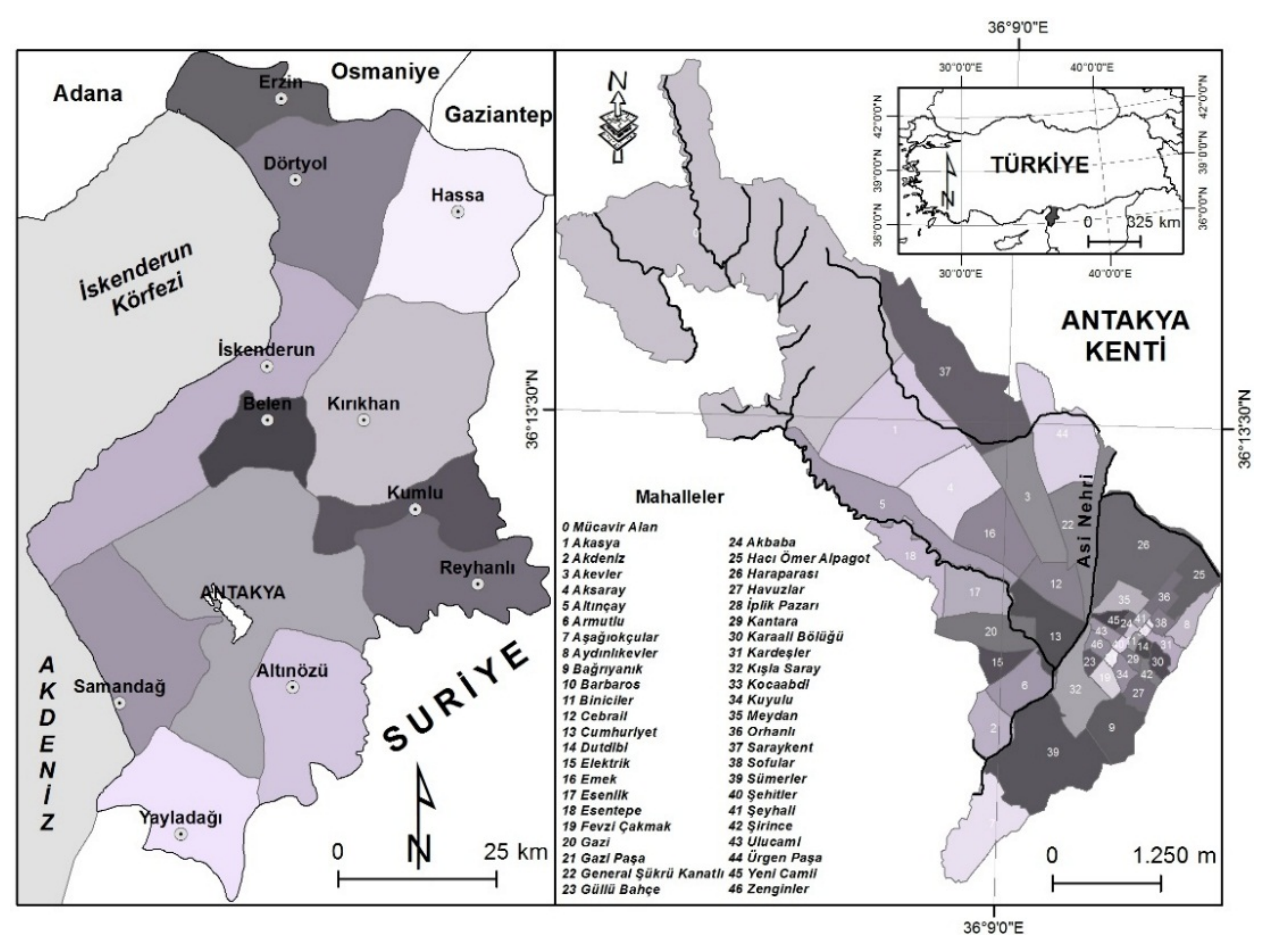

Şekil 1. İnceleme alanının konumu 


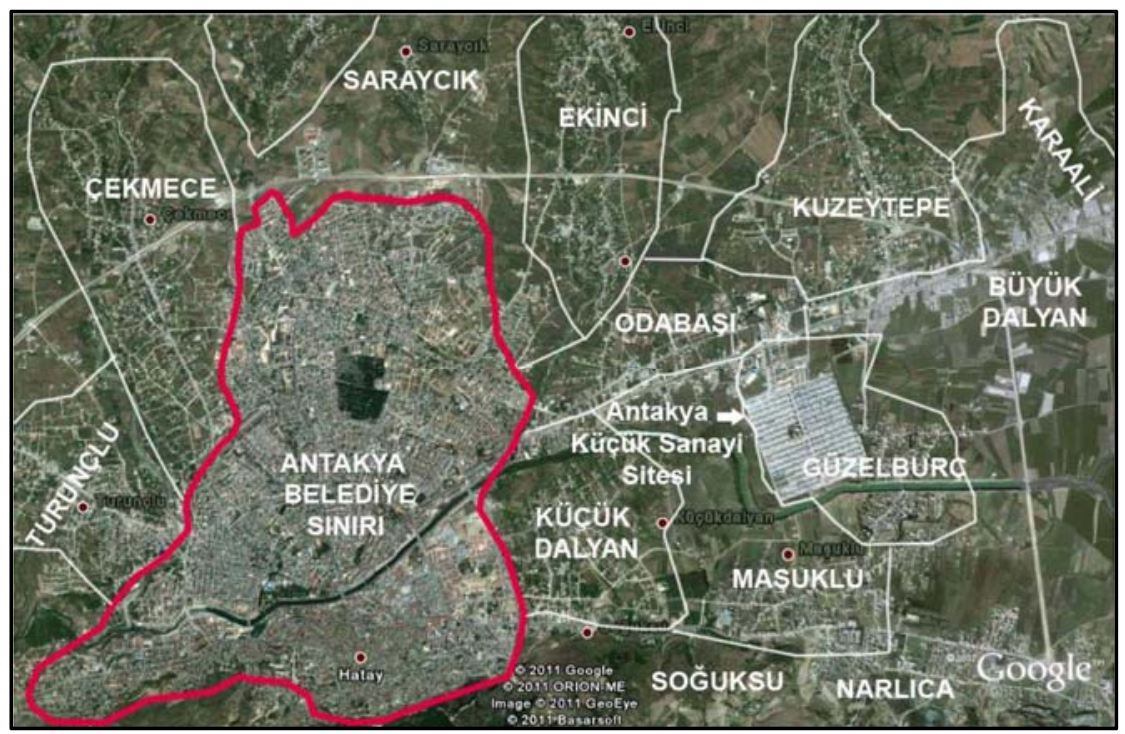

Şekil 2. İnceleme alanının günümüzdeki konumu (Çetin, 2012b: 273)

Antakya kenti sınırları içerisinde Mesozoyik’ten günümüze kadar çeşitli yaş ve türde jeolojik birimler bulunur. En yaşlı birim Kretase'ye ait neritik kireçtaşlarıdır. Bu birimin üzerinde Eosen'e ait neritik kireçtaşları bulunur. Eosen yaşlı istif, açısal uyumsuzlukla Miyosen'e ait kırıntılılar ve aynı yaştaki kırıntılılar ve karbonatlardan meydana gelen formasyonlarla kaplanmıştır. Bunların üzerinde ise uyumsuz olarak Pliyosen karasal kırıntılıları çökelmiştir. Bütün temel araziyi uyumsuz olarak Kuvaterner'e ait alüvyal çökeller örtmektedir (Ateş vd., 2004: 18; Özşahin, 2010: 4-6). Antakya kenti, coğrafi konumu itibariyle çok büyük ve farklı tektonik yapıların bir arada bulunduğu ve tektonik aktivitenin yoğun olarak hissedildiği bir alanda yer almaktadır. Bu saha genel hatlarıyla Doğu Anadolu, Ölü Deniz ve Kıbrıs-Antakya faylarının kesişim noktasında bulunmaktadır (Herece, 2008: 97; Özşahin, 2010: 6; Özşahin ve Özder, 2011: 662).

Antakya kenti, jeomorfolojik anlamda Amanos Dağları ile Kuseyr Platosu horstları arasındaki graben alanında yer alır. Jeomorfolojik açıdan çeşitlilik gösteren bu kent; dağ, plato ve ova gibi ana jeomorfolojik birimlerin yanında taraça, yamaç döküntüleri ve birikinti yelpazeleri gibi çok farklı özellikte elemanter yer şekillerine de sahiptir (Özşahin, 2010: 6; Özşahin ve Özder, 2011: 664).

Karakteristik Akdeniz ikliminin etkilerinin görüldüğü sahada, Antakya Meteoroloji İstasyonunun (100 m) 1970-2011 yılları arasını kapsayan iklim verilerine göre yıllık ortalama sıcaklık $18.3{ }^{\circ} \mathrm{C}$, yıllık toplam ortalama yağış ise 1078 mm'dir. Kış mevsiminde KD, ilkbahar yaz ve sonbaharda GB yönlü rüzgârlar hâkimdir. Thornthwaite yöntemine göre Antakya'da "Birinci dereceden nemli, üçüncü dereceden mezotermal, yaz mevsiminde çok kuvvetli su noksanı olan ve denizel şartlara yakın iklim tipi” (B1 B'3 s2 b'4) etkilidir (Korkmaz ve Fakı, 2009: 344). 
CBS ve AHS Kullanılarak Doğal Çevre Bileşenleri Açısından Kentsel Mekânın Yerleşime Uygunluk Analizine Bir Örnek: Antakya (Hatay)

İnceleme alanının başlıca hidrografik unsuru Asi Nehri ve onun kolları olan Hacı Kuriş, Hanna, Altınçay ve Kavaslı dereleridir. Bunun yanında kent merkezinde yeraltı suyu kullanımı yaygın olup, daha çok sondajlarla açılan kuyulardan istifade edilmektedir (Değerliyurt, 2013: 59).

Toprak Taksonomisine göre inceleme alanındaki toprakların nem rejimi "Xeric", sıcaklık rejimi de "Thermic" olarak tespit edilmiştir (Kılıç vd., 2008: 11). Yine aynı sınıflandırma esasına göre toprak serileri ise Entisol ve İnceptisol olmak üzere 2 ordo altında toplanabilir.

İnceleme alanının bulunduğu bölge, Türkiye bitki coğrafyası ve flora bölgelerine göre Holarktik Flora Aleminin Akdeniz Bölgesi sınırları içerisinde kalmaktadır (Atalay, 1994: 4). Vejetasyon formasyonları bakımından kuru ormanlar dâhilinde yer alan bu sahada hâkim bitki örtüsünü kızılçam (Pinus brutia) ormanları oluşturur. Ancak kent merkezinin yerleşim alanları tarafından kaplı olması doğal bitki örtüsünün çok sınırlı bir sahada kalmasına neden olmuştur. Bunun yanında kent sınırları içerisinde tarım alanları, bağ-bahçe alanları ve boş alanlar yayılış göstermektedir.

Tarihi çok eskilere dayanan bir yerleşim yeri olan Antakya M.Ö. 22 Mayıs 300 tarihinde Seleukos Kralı Seleukos I Nikator tarafından kurulmuştur (Korkmaz, 2007: 79; Bulut ve Korkmaz, 2008: 129; Özşahin ve Özder, 2011: 666). Stratejik konumu nedeniyle zamanla başkent olmuş ve her geçen gün daha da büyüyerek gelişmiştir (Pamir, 2009: 274). M.Ö. 64 yılında Roma hâkimiyetine giren Antakya, bu dönemde altın çağını yaşamış ve Doğu Akdeniz Havzasının en büyük kenti vasfını kazanmıştır. 638 yılında Müslüman Arapların egemenliği altına giren kent Roma dönemindeki ihtişamını Şam’a kaptırmıştır. 968 yılında tekrar Bizans hâkimiyetine giren kenti eski önemine kavuşturmak için büyük çaplı imar faaliyetleri gerçekleştirilmiştir. 12 Aralık 1804 yılında Selçukluların, Haziran 1098'de de Haçlıların hâkimiyetine giren Antakya, 18 Mayıs 1268'de el değiştirmemek üzere İslam devletinin egemenliği altına alınmıştır. Memlûkluların şehri ele geçirmesinden sonra bu bölgede Hristiyanlığın çöküşü hızlanmış, bu durum Antakya'nın ticari ve ekonomik gücünün azalmasına neden olmuştur. Yavuz Sultan Selim döneminde Osmanlı Devleti'nin yönetimine alınan kent, 1918 yılına kadar Halep vilayetinin Halep Merkez Sancağına bağlı bir "kaza merkezi” olarak yönetilmiştir (Korkmaz, 2007: 86; Bulut ve Korkmaz, 2008: 130). Hatay'ın 1939 yılında Türkiye Cumhuriyeti'ne katılması ile devam eden süreç, Antakya'da nüfusunun hızlı bir şekilde artmasına yol açmıştır (Özşahin ve Özder, 2011: 667). Günümüzde TUİK ADNKS (2010) tarafından sunulan 31.12.2010 tarihli verilerine göre Antakya'da 47 mahalle vardır. Bu mahallerde toplamda 213.581 kişi bulunmaktadır (Tablo 1; Foto 1). Gelecekteki nüfus projeksiyonlarına göre Antakya'da 2020 yılında 264.000-277.000, 2030 yılında yaklaşık 350.000-382.000, 2050 yılında ise 615.000-728.000 kişinin yaşayacağ öngörülmektedir (Çetin, 2010: 188). 
The Analysis of Habitability of Urban Spaces In Terms of Natural Environmental Components By Means of GIS and AHP: The Case of Antakya (Hatay)

Tablo 1. Antakya kentinin mahalleleri (2010)

\begin{tabular}{|l|r|l|r|l|r|}
\hline Mahalle Adı & Nüfusu & Mahalle Adı & Nüfusu & Mahalle Adı & Nüfusu \\
\hline Akasya & 18091 & Emek & 12570 & Kocaabdi & 390 \\
\hline Akbaba & 282 & Esenlik & 9904 & Kuyulu & 1736 \\
\hline Akdeniz & 2901 & Esentepe & 6083 & Meydan & 1105 \\
\hline Akevler & 14134 & Fevzi Çakmak & 1471 & Orhanlı & 1709 \\
\hline Aksaray & 9094 & Gazi & 8352 & Saraykent & 7679 \\
\hline Altınçay & 9358 & Gazi Paşa & 302 & Sofular & 1044 \\
\hline Armutlu & 9009 & General Şükrü & 10263 & Sümerler & 11828 \\
\hline Aşağıkçular & 229 & Güllü Bahçe & 617 & Şehitler & 788 \\
\hline Aydınlıkevler & 2572 & Hacı Ömer Alpagot & 7269 & Şeyhali & 978 \\
\hline Bağrıyanık & 4336 & Haraparası & 596 & Şirince & 1499 \\
\hline Barbaros & 558 & Havuzlar & 1424 & Ulucamii & 899 \\
\hline Biniciler & 687 & İplik Pazarı & 577 & Ürgen Paşa & 15153 \\
\hline Cebrail & 11107 & Kantara & 1013 & Yeni Camii & 302 \\
\hline Cumhuriyet & 8185 & Karaali Bölüğü & 2045 & Zenginler & 1273 \\
\hline Dutdibi & 1053 & Kardeşler & 1779 & Mücavir Alan & 0 \\
\hline Elektrik & 5515 & Kışla Saray & 5822 & TOPLAM & $\mathbf{2 1 3 5 8 1}$ \\
\hline
\end{tabular}

Kaynak: TUİK ADNKS, 2010 
CBS ve AHS Kullanılarak Doğal Çevre Bileşenleri Açısından Kentsel Mekânın Yerleşime Uygunluk Analizine Bir Örnek: Antakya (Hatay)

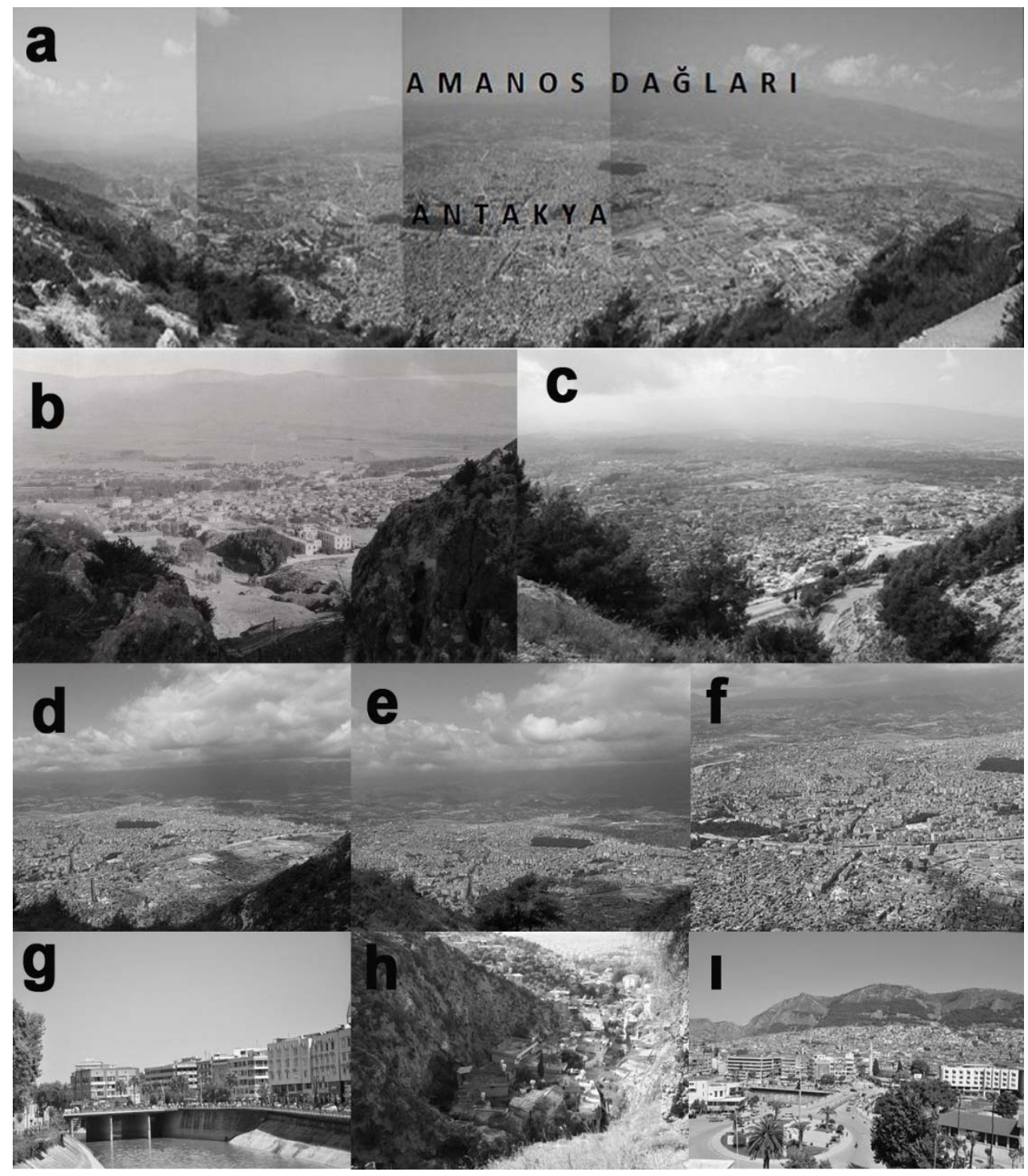

Foto 1. (a) Antakya kentinden genel bir görünüm, (b) Antakya'nın 1900'lü yıllarında başındaki hali, (c) Antakya'nın günümüzdeki hali, (d, e, f) Antakya'dan farklı görünümler, (g) Antakya'nın içerisinden geçen Asi Nehri ve çevresi, (h) Kütle hareketi riski olan Bağrıyanık Mahallesi'nden bir görünüm, (1) Eski Antakya ve Habibi Neccar Dağı'ından bir görünüm. 
The Analysis of Habitability of Urban Spaces In Terms of Natural Environmental Components By Means of GIS and AHP: The Case of Antakya (Hatay)

\section{MATERYAL VE METOT}

\section{1. Materyal}

Antakya kentinin doğal çevre bileşenlerinin yerleşmeye elverişliliği bakımından uygun yer seçimi analizinin yapıldığı bu çalışmada; çok farklı kurumlardan, çok farklı veri türleri şeklinde alınan çeşitli haritalardan yararlanılmıştır (Tablo 2). Böylece değerlendirme ve analiz, daha hassas bir şekilde gerçekleştirilmiştir. Analiz için faktör haritalarının oluşturulmasında temel altlık olarak 1/25.000 ölçek oranı esas alınmıştır. Çalışmadaki faktör haritalarının üretilmesinde ve görüntü analizlerinde CBS yazılımlarından ArcGIS/ArcMap 10.1 paket programı kullanılarak gerçekleştirilmiştir.

Tablo 2. Çalışmada kullanılan veriler, türleri ve tedarik edildiği kaynaklar

\begin{tabular}{|l|c|l|}
\hline \multicolumn{1}{|c|}{ Veri } & Veri Türü & \multicolumn{1}{c|}{ Kaynak } \\
\hline Litoloji & Raster & Ateş vd., 2004; Herece, 2008; Özşahin, 2010 \\
\hline Fay hatlarına mesafe (m) & Raster & Ateş vd., 2004; Herece, 2008; Özşahin, 2010 \\
\hline Yerşekilleri & Raster & Özşahin, 2010 \\
\hline Yükseklik (m) & Raster & $\begin{array}{l}\text { Harita Genel Komutanlığı 1/25.000 ölçekli } \\
\text { Topografya haritaları }\end{array}$ \\
\hline Eğim & Raster & $\begin{array}{l}\text { Harita Genel Komutanlığı 1/25.000 ölçekli } \\
\text { Topografya haritaları }\end{array}$ \\
\hline Bakı & Raster & $\begin{array}{l}\text { Harita Genel Komutanlığı 1/25.000 ölçekli } \\
\text { Topografya haritaları }\end{array}$ \\
\hline Sıcaklık $\left({ }^{\circ} \mathrm{C}\right)$ & Vektör & $\begin{array}{l}\text { T.C. Devlet Meteoroloji İşleri Genel } \\
\text { Müdürlüğü 1970-2011 yıllarına ait iklim } \\
\text { verileri }\end{array}$ \\
\hline Yağ1ş (mm) & Vektör & $\begin{array}{l}\text { T.C. Devlet Meteoroloji İşleri Genel } \\
\text { Müdürlüğü 1970-2011 yıllarına ait iklim } \\
\text { verileri }\end{array}$ \\
\hline Akarsulara mesafe (m) & Raster & $\begin{array}{l}\text { Harita Genel Komutanlığ1 1/25.000 ölçekli } \\
\text { Topografya haritaları }\end{array}$ \\
\hline Yeraltı suyu derinliği (m) & Raster & Antakya Belediyesi \\
\hline Toprak & Vektör & T.C. Gıda, Tarım ve Hayvancılık Bakanlığ1 \\
\hline Arazi örtüsü ve kullanımı & Vektör & T.C. Gıda, Tarım ve Hayvancılık Bakanlığ1 \\
\hline
\end{tabular}

\section{2. Metot}

Çalışmanın amacına bağlı olarak yöntem olarak CBS tabanlı uygulamaların karar verme sürecinde kullanılan çok kriterli karar verme yöntemlerinden biri olan AHS'den yararlanılmıştır. Zira bu yöntem sadeliği, kolay kullanılabilirliği ve anlaşılabilir bir metot olması nedeniyle çok kriterli karar verme yöntemleri arasında sıkça başvurulan bir tekniktir (Aktaş vd., 2001: 218; Akdeniz ve Turgutlu, 2007: 5; Soba ve Bildik, 2013: 54). Çalışmamızda AHS, SCB Associates Ltd tarafından geliştirilen AHP Template yazılımı kullanılarak gerçekleştirilmiştir. Bunun için öncelikle çalışma amacı belirlenmiş (hedef) ve bu amaç doğrultusunda seçimi etkileyen kriterler ortaya konmuştur. Daha sonra bu kriterler göz önüne alınarak alternatifler tespit edilmiş ve hiyerarşik bir yapı oluşturulmuştur 
CBS ve AHS Kullanılarak Doğal Çevre Bileşenleri Açısından Kentsel Mekânın Yerleşime Uygunluk Analizine Bir Örnek: Antakya (Hatay)

(Dağdeviren ve Eren, 2001: 43; Scholl vd., 2005: 763; Toksar1, 2007: 173; Şekil 3). Bunun akabinde ilk aşamada tespit edilen kriterler ve alternatifler Saaty (1994: 26) tarafindan ortaya konan önem ölçeğine (Tablo 3) göre kıyaslanmış ve bu ölçek yardımıyla 1 ile 9 arasında derecelendirilmiştir (Saaty, 1994: 26). Bu derecelendirme literatürde bildirilen ölçütlere göre gerçekleştirilmiştir.

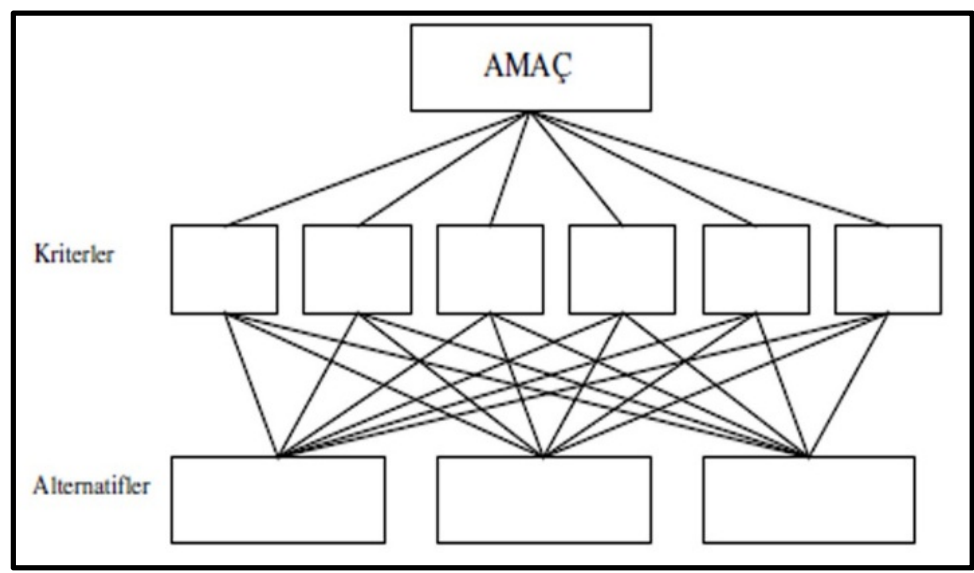

Şekil 3. Üç aşamalı AHS modeli (Saaty ve Vargas, 2001: 3)

Tablo 3. Önem ölçeği

\begin{tabular}{|c|l|}
\hline Önem Derecesi & \multicolumn{1}{|c|}{ Tanım } \\
\hline 1 & Eşit önem \\
\hline 3 & Orta derecede önemli olması \\
\hline 5 & Kuvvetli düzeyde önemli \\
\hline 7 & Çok kuvvetli düzeyde önemli \\
\hline 9 & Son derece önemli \\
\hline $2,4,6,8$ & $\begin{array}{l}\text { İki faaliyet arasında kalan ara } \\
\text { değerler }\end{array}$ \\
\hline
\end{tabular}

Kaynak: Saaty, 1986: 843

Karşılaştırmalı karar verme ve tercih matrisinin oluşturulması safhasında daha öncesinde tespit edilen kriterler ve alternatifler birbiriyle karşılaştırılmıştır. Bu kıyasta karşılaştırma yapılacak hiyerarşi düzeyinde " $n$ " sayıda eleman bulunduğunda "n (n-1)/2" adet karşılaştırma yapmak gerekmiş ve her bir karşılaştırma matris şeklinde düzenlenmiştir (Byun, 2001: 290; Arslan, 2010: 458). Daha sonra ölçek katsayıları belirlenen kriterlerin ve alternatiflerin AHP Template programı kullanılarak yüzde önem ağırlıkları (Toksarı, 2007: 172) tutarlılığ 1 geçerli olacak bir şekilde (Saaty ve Vargas, 2001: 9; Kwiesielewicz ve Uden, 2004: 713-714; Arslan, 2010: 459; Dündar ve Ecer, 2008: 200) elde edilmiştir (Tablo 4). Tutarlılığın geçerliliği, tutarlılık indeksi ve oranının hesaplanmasıyla kontrol edilmiştir. A matrisinin tutarlılık oranının hesaplanmasında aşağıdaki formüller kullanılmıștır (Shrestha vd., 2004: 187- 188); 
The Analysis of Habitability of Urban Spaces In Terms of Natural Environmental Components By Means of GIS and AHP: The Case of Antakya (Hatay)

Tablo 4. Ölçek katsayıları belirlenen kriterler ve alternatiflerin ağırlık değerleri

\begin{tabular}{|c|c|c|c|c|}
\hline Kriterler & Sembol & Ăğırlık & Alternatifler & Ăğırlık \\
\hline \multirow{7}{*}{ Litoloji } & \multirow{7}{*}{$\mathrm{Li}$} & \multirow{7}{*}{0.195} & Alüvyon/Kuvaterner & 0.029 \\
\hline & & & Kumtaş1, killi kireçtaş1, kiltaş1/Pliyosen & 0.040 \\
\hline & & & Kumtaşı, killi kireçtaş1/Orta Miyosen & 0.064 \\
\hline & & & Resifal Kireçtaşı/Orta Miyosen & 0.202 \\
\hline & & & Konglomera, kumtaş1/Alt Miyosen & 0.079 \\
\hline & & & Kireçtaş1, detritik kireçtaş1/Alt-Orta Eosen & 0.369 \\
\hline & & & Peridotit, serpantin/Üst Kretase & 0.218 \\
\hline \multirow{6}{*}{$\begin{array}{l}\text { Fay hatlarına } \\
\text { mesafe }(\mathrm{m})\end{array}$} & \multirow{6}{*}{$\mathrm{F}$} & \multirow{6}{*}{0.087} & $<-15$ & 0.043 \\
\hline & & & $15.01-30$ & 0.052 \\
\hline & & & $30.01-45$ & 0.066 \\
\hline & & & $45.01-60$ & 0.100 \\
\hline & & & $60.01-75$ & 0.210 \\
\hline & & & $75.01->$ & 0.528 \\
\hline \multirow{6}{*}{ Yerşekilleri } & \multirow{6}{*}{$\mathrm{Yr}$} & \multirow{6}{*}{0.312} & Plato & 0.523 \\
\hline & & & Ova & 0.066 \\
\hline & & & Yamaç & 0.213 \\
\hline & & & Taraça & 0.110 \\
\hline & & & Birikinti Yelpazesi & 0.044 \\
\hline & & & Yamaç Döküntüsü & 0.044 \\
\hline \multirow{4}{*}{ Yükseklik (m) } & \multirow{4}{*}{ Yks } & \multirow{4}{*}{0.054} & $>-100$ & 0.593 \\
\hline & & & $100.01-200$ & 0.225 \\
\hline & & & $200.01-300$ & 0.112 \\
\hline & & & $300.01->$ & 0.069 \\
\hline \multirow{5}{*}{ Eğim } & \multirow{5}{*}{$\mathrm{E}$} & \multirow{5}{*}{0.059} & $<-2$ & 0.047 \\
\hline & & & $2-8$ & 0.067 \\
\hline & & & $8-16$ & 0.111 \\
\hline & & & $16-24$ & 0.219 \\
\hline & & & $24->$ & 0.555 \\
\hline \multirow{5}{*}{ Bakı } & \multirow{5}{*}{ B } & \multirow{5}{*}{0.023} & Düz & 0.047 \\
\hline & & & $\mathrm{K}$ & 0.073 \\
\hline & & & $\mathrm{G}$ & 0.136 \\
\hline & & & $\mathrm{D}$ & 0.372 \\
\hline & & & $\mathrm{B}$ & 0.372 \\
\hline \multirow{4}{*}{ Sicaklık $\left({ }^{\circ} \mathrm{C}\right)$} & \multirow{4}{*}{$\mathrm{S}$} & \multirow{4}{*}{0.023} & $<-18.3$ & 0.593 \\
\hline & & & $18.3-17.3$ & 0.225 \\
\hline & & & $17.3-16.3$ & 0.112 \\
\hline & & & $16.3->$ & 0.069 \\
\hline & & & $<-1112$ & 0.593 \\
\hline Voŭı1 (mm) & & 0023 & $1112.01-1166$ & 0.225 \\
\hline Yağ1ş (mm) & $\mathrm{Y}$ & 0.023 & $1166.01-1220$ & 0.112 \\
\hline & & & $1220.01->$ & 0.069 \\
\hline & & & $<-36$ & 0.047 \\
\hline & & & $36.01-72$ & 0.067 \\
\hline Akarsulara & $\mathrm{A}$ & 0.035 & $72.01-108$ & 0.111 \\
\hline & & & $108.01-144$ & 0.219 \\
\hline & & & $144.01->$ & 0.555 \\
\hline & & & $<--2$ & 0.069 \\
\hline Yeraltı suyu & $\mathrm{Y}_{\mathrm{S}}$ & 0028 & $-2.01--4$ & 0.112 \\
\hline derinliği (m) & YS & 0.028 & $-4.01--6$ & 0.225 \\
\hline & & & $-6.01->$ & 0.593 \\
\hline
\end{tabular}


CBS ve AHS Kullanılarak Doğal Çevre Bileşenleri Açısından Kentsel Mekânın Yerleşime Uygunluk Analizine Bir Örnek: Antakya (Hatay)

\begin{tabular}{|l|c|c|l|c|}
\hline \multirow{2}{*}{ Toprak } & \multirow{2}{*}{$\mathrm{T}$} & \multirow{2}{*}{0.034} & İnceptisol & 0.834 \\
\cline { 3 - 4 } & & Entisol & 0.166 \\
\hline \multirow{4}{*}{$\begin{array}{c}\text { Arazi kullanımı } \\
\text { ve arazi örtüsü }\end{array}$} & \multirow{4}{*}{ AKAÖ } & \multirow{4}{*}{0.127} & Yerleşim Alanları & 0.484 \\
\cline { 4 - 5 } & & Bağ ve Bahçe Alanları & 0.064 \\
\cline { 4 - 5 } & & Sulu Tarım Alanları & 0.048 \\
\cline { 4 - 5 } & & Kuru Tarım Alanları & 0.059 \\
\cline { 4 - 5 } & & Mera Alanları & 0.200 \\
\cline { 4 - 5 } & & Çalılı Alanlar & 0.107 \\
\cline { 4 - 5 } & & Orman Alanları & 0.039 \\
\hline
\end{tabular}

$\mathrm{CR}=\mathrm{CI} / \mathrm{RI}$

$\mathrm{CI}=\left(\lambda_{\max }-\mathrm{n}\right) /(\mathrm{n}-1)$

CI: Tutarlılık İndeksi (Consistency Index)

RI: Rastgele İndeks (Random Index)

CR: Tutarlılık Oranı (Consistency Ratio)

Buna göre tutarlılık oranı (CR) genellikle \% 10 veya daha küçükse matrisin tutarlı olduğu kabul edilmektedir (Wind ve Saaty, 1980: 646; Saaty vd., 2003: 174). Ayrıca en büyük öz değer matris boyutuna eşit ise $(\lambda \max =n)$ karşılaştırma matrisi tutarlı olarak ifade edilir (Shrestha vd., 2004: 187; Arslan, 2010: 459).

Yöntemin son aşamasında ise elde edilen ağırlık değerleri vektör veri formatındaki alternatif etkenlerin haritalarına işlenmiştir. Daha sonra bu vektör haritaları aşağıdaki formüle (1) göre analiz edilmiş ve yerleşime uygunluk haritası elde edilmiştir.

$U Y S A=(\operatorname{Li} \times 0.195)+(F \times 0.087)+(\operatorname{Yr} \times 0.312)+(Y k s \times 0.054)+(E \times 0.059)+$ $(B \times 0.023)+(S \times 0.023)+(Y \times 0.023)+(A \times 0.035)+(Y s \times 0.028)+(T \times 0.034)+(A K A \ddot{O}$ $x 0.127)(1)$

Burada: UYSA (Uygun Yer Seçimi Analizi) hedef, Li (Litoloji), F (Fay hatlarına mesafe), Yr (Yerşekilleri), Yks (Yükseklik), E (Eğim), B (Bakı), S (Sıcaklık), Y (Yağış), A (Akarsulara mesafe), Ys (Yeraltı suyu seviyesi), T (Toprak) ve AKAÖ (Arazi kullanımı ve arazi örtüsü) ise kriterlerdir. Çalışmada yapılan analiz 10x10 m çözünürlüğünde raster tabanlı olarak gerçekleştirilmiş ve analiz sonuçları, Çok uygun, Uygun, Az uygun ve Uygunsuz olmak üzere dört seviyeye göre sınıflandırılmıştır.

\section{BULGULAR}

Doğal çevre özellikleri bakımından uygun alana kurulmayan kentlerin büyük bölümü çeşitli doğal risklerle karşı karşıyadır (Tonbul ve Sunkar, 2008: 108; Özşahin, 2010: 8). Özellikle Türkiye'nin \% 97'sinin sismik hareketler, \% 40'tan fazlasının da yer kaymaları, sel ve taşkınlar açısından can ve mal kayıplarına neden olabilecek bir risk altında (Girgin, 1995: 155; Cürebal, 2004: 76) olduğu düşünüldüğünde bu durum daha net açıklanabilmektedir. Antakya kenti de kuruluşundan günümüze kadar çeşitli doğal risklerin etkisi altında kalmıştır. Kent alanı, jeomorfolojik özelliklerden kaynaklanan taşkın ve kütle 
The Analysis of Habitability of Urban Spaces In Terms of Natural Environmental Components By Means of GIS and AHP: The Case of Antakya (Hatay)

hareketleri ile zemin özelliklerinden kaynaklanan deprem riski altındadır (Özşahin, 2010: 8). Zira kent tarihinde yaşanan çok sayıda afetten dolayı maddi hasar ve ölüm gerçekleşmiştir (Tablo 5). Bu bölümde Antakya'nın doğal çevre bileşenlerinin yerleşime uygunluk açısından etkisi sorgulanmıştır.

Tablo 5. Antakya kent tarihinde meydana gelen afetler ve etkileri

\begin{tabular}{|c|c|c|c|}
\hline Afet Türü & Tarih & Etkisi & Kaynak \\
\hline Taşkın & $\begin{array}{l}1956-1969-1975- \\
1976-1980-1985- \\
1987-1988-2001- \\
2009-2012\end{array}$ & $\begin{array}{l}\text { Maddi hasar ve } \\
\text { ölüm }\end{array}$ & $\begin{array}{l}\text { Özşahin ve Kaymaz, } \\
2013 b\end{array}$ \\
\hline $\begin{array}{l}\text { Kütle } \\
\text { Hareketleri }\end{array}$ & $\begin{array}{l}12.02 .1992- \\
11.03 .1997- \\
12.11 .1988- \\
09.01 .1990\end{array}$ & Maddi hasar & $\begin{array}{l}\text { Antakya Belediyesi, } \\
\text { 2006; Özşahin, 2010; } \\
\text { Değerliyurt, } 2013\end{array}$ \\
\hline Deprem & $\begin{array}{l}\text { M.Ö. } 69 \text { - M.S. } 115 \text { - } \\
365 \text { - } 458 \text { - } 29 \text { May1s } \\
525 \text { - } 528 \text { - } 551 \text { - } 557 \\
-577 \text { - } 588 \text { - May1s } \\
1406 \text { - } 10 \text { Haziran } \\
1537 \text { - } 29 \text { Mayis } \\
1538 \text { - } 25 \text { Eylül } 1738 \\
\text { - } 1759 \text { - } 1872\end{array}$ & $\begin{array}{l}\text { Maddi hasar ve } \\
\text { ölüm }\end{array}$ & $\begin{array}{l}\text { Korkmaz, 2006; } \\
\text { Değerliyurt, 2013; } \\
\text { Özşahin ve } \\
\text { Değerliyurt, } 2013\end{array}$ \\
\hline
\end{tabular}

İnceleme alanı litolojik özellikler bakımından çeşitlilik sunar. Bu nedenle litolojik birimlerin yerleşime uygunluk açısından duyarlılık değeri de farklılık göstermektedir. Litolojik birimlerin tanımlanması ve dayanımlılık derecesine göre yapılan zemin mukavemet özelliklerine göre değerlendirilmiştir (Korkmaz, 2006: 56). Zira bu değerlendirme zemin tabiatını ve dolayısıyla yerleşime uygunluk açısından karakterini yansıtmaktadır. Buna göre Antakya'da Kuvaterner'e ait alüvyonlar düşük ağırlık, Alt-Orta Eosen'e ait kireçtaşı ve detritik kireçtaşları yüksek ağırlık değerleri gösterir (Tablo 4). Yapılan puanlamaya göre inceleme alanındaki litolojik birimler \% 6 tutarlılık oranına sahiptir.

Yeryuvarının jeolojik geçmişte meydana gelen tektonik hareketler çeşitli boyut ve türde fay hatlarının oluşumuna neden olmuştur. Antakya'da da aynı bu türden bir etki neticesinde faylar oluşmuştur. Bu faylar özellikle yerleşime uygunluk açısından oldukça önemlidir. Bu konuda kesin bir uzaklık bildirilmemesine rağmen, Türkiye'de yerleşim alanlarının planlanmasında bu değerin en az 15 m'den az olmaması gerektiği önerisinde bulunulmuştur (Demirtaş, 2003: 53). Bu kapsamda inceleme alandaki fay hatlarına mesafe 15 m olarak ayrılmış ve puanlanmıştır (Tablo 4). AHS'ye göre yapılan değerlendirmede fay hatlarına uzaklık faktörü \% 8 tutarlılık oranına sahiptir.

İnceleme alanında farklılığı belirgin olmasa da yükseklik, yerleşime uygunluk açısından belirleyicilik taşımaktadır (Yalçınlar, 1967: 55; Özdemir, 1996: 212; Erkal ve Taş, 2013: 273). Bu bağlamda yüksek alanlar alçak sahalara göre yerleşime uygunluk açısından 
CBS ve AHS Kullanılarak Doğal Çevre Bileşenleri Açısından Kentsel Mekânın Yerleşime Uygunluk Analizine Bir Örnek: Antakya (Hatay)

daha az tercih edilen yerlerdir ve alternatif faktörlerin ağırlık değerleri yükseklik arttıkça düşmektedir. Yükseklik kriteri \% 6 tutarlılık oranı gösterir.

Kentleşmede etkili olan jeomorfolojik faktörlerden en önemlisi, yerşekilleridir (Bilgin, 1989: 35). İnceleme alanındaki yerşekilleri de yerleşime uygunluk açısından belki de en belirleyici rolü oynamaktadır. Bu bakımdan farklı yerşekilleri üzerinde bulunan Antakya'da, yerleşime uygunluk açısından plato yüksek ağırlık, ova ise düşük ağırlık değerlerine sahiptir. Bu kriterin tutarlılık oranı ise \% 8 olarak tespit edilmiştir.

Yerleşime uygunluk açısından eğim faktörü de önemli bir koşuldur (McBride, 1999: 65). Buna göre inceleme alanındaki eğim değerlerinin puanlaması ABD Jeolojik Araştırmalar Kurumu'nun kullandığı değerler (McBride, 1999: 66) göz önünde bulundurularak yapılmıştır. Eğim değeri arttıkça alternatiflerin ağırlıkları düşmektedir (Tablo 4). Eğim kriterinin tutarlılık oranı $\%$ 8'dir.

Bakı özellikleri de yerleşime uygunluk açısından göz önünde bulundurulması gereken bir kriterdir (Aliağaoğlu ve Uğur, 2010: 100). Özellikle Kuzey Yarım Küre için kuzeye bakan yamaçlar daha fazla radyasyon alan güneye bakan yamaçlara göre nemlilik ve buna bağlı olarak bitki örtüsünün varlığı bakımından zengin bir karakter gösterirler. $\mathrm{Bu}$ durum infiltrasyonu arttırıcı ve yüzeysel akışı azaltıcı bir etki oluşturduğu için yerleşime uygunsuz şartlar sağlar. Buna karşın güney yamaçlarda durum bu anlatılan mekanizmanın tersine taşkın açısından daha olumlu bir havanın esmesine neden olmaktadır (Yalçınlar, 1967: 56; Özdemir, 1996: 211). Buna göre inceleme alanında bakı sınıflarının ağırlıkları kuzey’de daha az, güneyde ise daha fazladır (Tablo 4). Bakı kriterinin tutarlılık oranı \% 3 olarak belirlenmiştir.

İnceleme alanında sıcaklık ve yağış kriterlerinin etkisi 100 m yükseltideki Antakya Meteoroloji istasyonun verileri göz önünde bulundurularak, yükseltiye bağlı sıcaklık ve yağış değişim ilkelerine göre enterpolasyonla elde edilmiştir. Sıcaklık değerleri her 100 m'de 0.5 ${ }^{\circ} \mathrm{C}$ sıcaklığın azalması ilkesine göre ortaya konan $\mathrm{Ti}=\mathrm{Tg}+(\mathrm{h} \times 0.5: 100)$ formülüne göre (Erol, 2004: 80), yağış değerleri ise Schreiber tarafından önerilen her 100 m'de 54 mm yağışın artması ilkesi göz önünde bulundurularak geliştirilen $\mathrm{Ph}=\mathrm{Po}+4.5 \mathrm{xh}$ formül yardımıyla (Ardel vd., 1969: 195; Dönmez, 1979: 177) tespit edilmiştir. Sıcaklık kriterinin alternatiflerinin ağırlıkları termal konfor aralığına göre (Topay, 2013: 113), kentte sıcaklık değerlerinin 18 ${ }^{\circ} \mathrm{C}$ 'nin üzerinde olduğu yerler en konforlu, altında olduğu yerler ise daha az konforlu olacak şeklinde puanlandırılmıştır (Tablo 4). Yağış arttıkça yerleşime uygunluk azaldığı için bu kriterin alternatiflerinin ağırlıkları yağış miktarının değişime göre puanlandırılmıştır (Tablo 4). İnceleme alanında sıcaklık ve yağış kriterleri \% 6 tutarlılık oranına sahiptir.

Akarsu ağlarından uzaklık (m) faktörü, yerleşime uygunluğu belirleyici önceliğe sahiptir (Özşahin, 2012: 380). İnceleme alanında akarsulardan uzaklaştıkça yerleşime uygunluk artmaktadır (Tablo 4). Zira Asi Nehri'nin her iki yakasında $100 \mathrm{~m}$ ve Altınçay Deresi'nde ise $36 \mathrm{~m}$ içerisinde iskân amaçlı kullanımlara yer verilmemesi gerektiği belirtilmiştir (Özşahin, 2010: 9). Bu nedenle inceleme alanında akarsulara uzaklık (m) faktörü 36 m'lik zonlar şeklinde puanlanmış ve tutarlılık oranı \% 8 olarak hesaplanmıştır. 
The Analysis of Habitability of Urban Spaces In Terms of Natural Environmental Components By Means of GIS and AHP: The Case of Antakya (Hatay)

Zemindeki yeraltı su seviyesinin derinliği de başta deprem olmak üzere birçok doğal afetin hasarının büyümesinde önemli bir etken olarak görülmektedir (Özşahin ve Değerliyurt, 2013: 44). İnceleme alanında yeraltı su seviyesi faktörü Asi Nehri vadisinden çevreye doğru azalmaktadır. Yapılan puanlamaya göre (Tablo 4) yeraltı suyu faktörünün tutarlılık oranı \% 8 'dir.

Yerleşime uygunluk bakımından toprak önemli bir faktördür. Antakya kenti için bu faktörün etkisi, birinci derecede tarımsal üretime uygunluk kapasitesi kapsamında ele alınmıştır. Buna göre İnceptisoller daha yüksek, Entisoller daha düşük ağırlıklarına sahiptirler (Tablo 4). Bu kriterin tutarlılık oranı, \% 1'dir.

Antakya kentindeki arazi kullanımı ve arazi örtüsü (AKAÖ) özellikleri de yerleşime uygunluk üzerinde etkili rol oynamaktadır (Özşahin, 2012: 381). Bu faktörün bilinçsiz bir şekilde değiştirilmesi güncel yerleşim alanında plansız ve kontrolsüz bir büyümeye neden olmuştur (Çetin, 2012a: 255; 2012b: 279). Antakya kentindeki arazi kullanımı ve arazi örtüsü (AKAÖ) yerleşme, sulu ve kuru tarım alanları, bağ-bahçe alanları, mera alanları, çalılık alanlar ve orman alanları olmak üzere yedi sınıf altında gruplandırılmıştır. Daha sonra bu grup alternatiflerine yerleşime uygunluk açısından ağırlık değerleri verilmiş (Tablo 4) ve kriterin tutarlılık oranı, $\% 9$ olarak tespit edilmiştir.

Antakya kenti için yerleşime uygunluk açısından yukarıda açıklanan kriterler arasındaki ağırlık değerleri tespit edilmiş ve tutarlılık oranı \% 5 olarak belirlenmiştir. Daha sonra bu kriterlerin yöntem kısmındaki formüle (1) göre analizi sonucunda yerleşime uygunluk açısından kentin yaklaşık yarısından fazlasının $\left(12.7 \mathrm{~km}^{2}\right.$ - \% 59.4) yerleşmeye az uygun $(0.25-0.35)$ olduğu tespit edilmiştir (Tablo 6). Az uygun sınıf daha çok kentin günümüzdeki hâlihazırda bulunduğu sahaya karşılık gelmektedir (Şekil 4). Yerleşime uygunluk açısından en küçük alanı $\left(0.2 \mathrm{~km}^{2}-\% 0.8\right)$ ise çok uygun $(<-0.15)$ değer sınıfı oluşturmaktadır (Tablo 6). Bu sınıf, Esenlik ve Gazi mahallelerinin sınırında ve mücavir alan sınırları dâhilinde yayılış gösterir. Diğer yerleşime uygunluk sınıfları ise uygun $(0.15-0.25)$ ve uygunsuz $(0.35->)$ sinıflardır (Tablo 6). Bu sinıflar sirasıyla \% $33.5\left(7.2 \mathrm{~km}^{2}\right)$ ve \% 6.3 $\left(1.3 \mathrm{~km}^{2}\right)$ oranında yayılışa sahiptirler (Tablo 6). Yerleşime uygunluk bakımından uygun sahalar daha yoğun olarak mücavir alan sınırları içerisinde, uygunsuz sahalarda kentteki akarsu vadileri ve fay hatlarının geçtiği güzergâhlarda yoğunlaşmaktadır (Şekil 4).

Tablo 6. Antakya kentinin yerleşime uygunluk sınıfları ve değerleri

\begin{tabular}{|c|c|c|c|}
\hline \multirow{2}{*}{ Yerleşime uygunluk sınıfları } & \multirow{2}{*}{ Yerleşime uygunluk değerleri } & \multicolumn{2}{|c|}{ ALAN } \\
\cline { 3 - 4 } & & $\mathbf{k m}^{\mathbf{2}}$ & $\mathbf{\%}$ \\
\hline Çok uygun & $<-0.15$ & 0.2 & 0.8 \\
\hline Uygun & $0.15-0.25$ & 7.2 & 33.5 \\
\hline Az uygun & $0.25-0.35$ & 12.7 & 59.4 \\
\hline Uygunsuz & $0.35->$ & 1.3 & 6.3 \\
\hline \multicolumn{2}{|r}{ TOPLAM } & $\mathbf{2 1 . 4}$ & $\mathbf{1 0 0 . 0}$ \\
\hline
\end{tabular}


CBS ve AHS Kullanılarak Doğal Çevre Bileşenleri Açısından Kentsel Mekânın Yerleşime Uygunluk Analizine Bir Örnek: Antakya (Hatay)

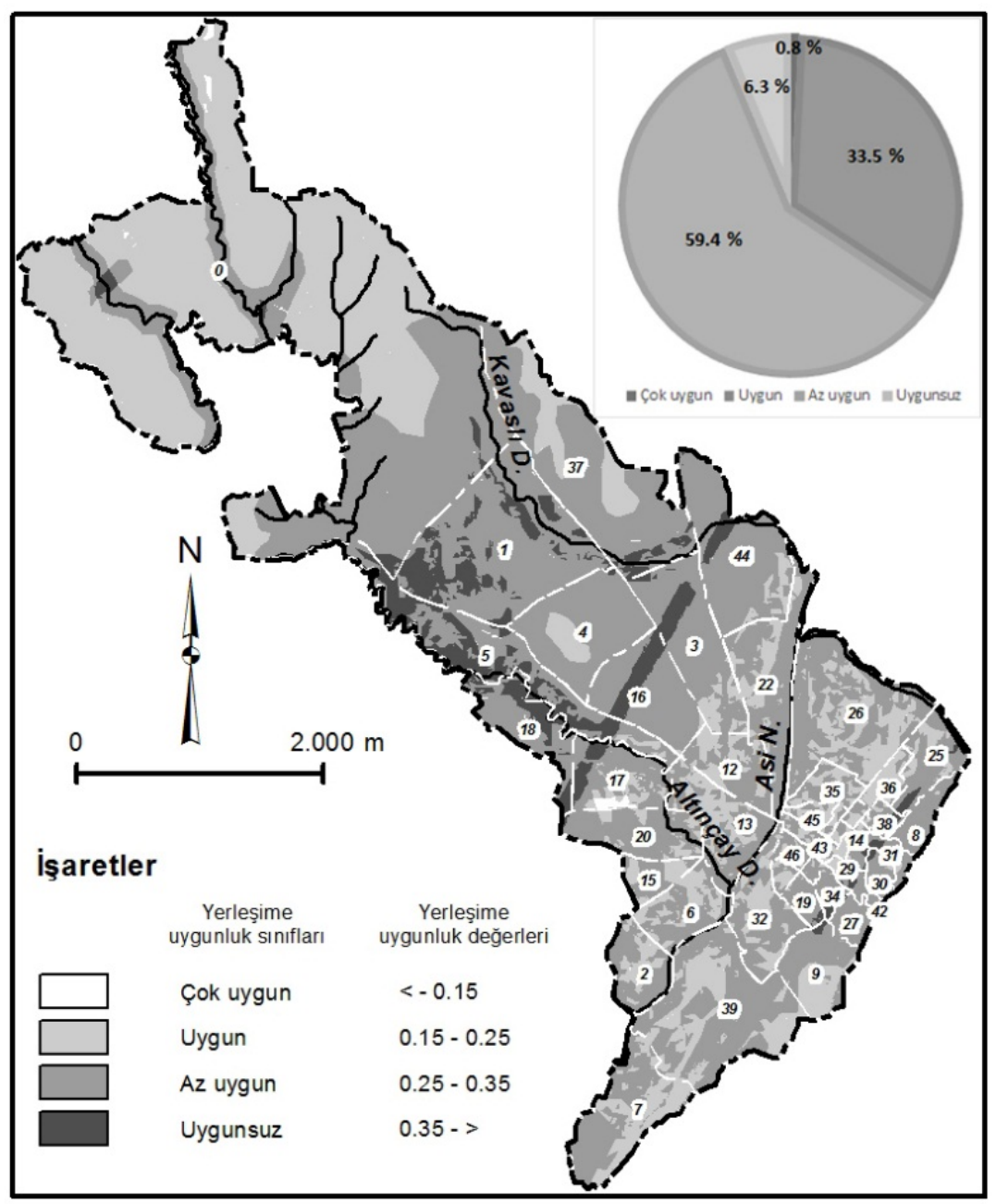

Şekil 4. Antakya kentinin yerleşime uygunluk haritası

\section{TARTIŞMA VE SONUÇ}

Kentsel çevrenin sürdürülebilir ve yaşanabilir anlamda planlanabilmesi için uygun bir yerleşim düzeni/mekân organizasyonun yapılması gerekmektedir. Bu ise işleyen doğal çevre bileşenleri arasındaki bağlılığın bilimsel yöntemlerle araştırılarak kontrol altında tutulması ve denetlenmesiyle gerçekleştirilebilir. Aksi takdirde kentin dejenere olması ile birlikte doğal çevre bileşenlerinin işleyişi ile bağdaşmayan sorunlar ortaya çıkmaktadır. $\mathrm{Bu}$ durum kentte düzensizlik ve rahatsızlık ortaya çıkarmakta ve zamanla yaşanabilir kent olmaktan uzaklaştıran sonuçlar doğurmaktadır (Çetin, 2012a: 255). 
The Analysis of Habitability of Urban Spaces In Terms of Natural Environmental Components By Means of GIS and AHP: The Case of Antakya (Hatay)

Doğal çevre bileşenlerinin bir örnek dahilinde yerleşime uygunluğunun değerlendirildiği bu çalışmada, Antakya'nın yerleşmeye az uygun bir sahada olduğu saptanmıştır. Zira bu durum inceleme alanındaki kentleşmeyi konu alan yapıllmış çalışmalarda da (Çetin, 2012a: 255; 2012b: 279) dile getirilmiştir. Bunun yanında kent alanında yerleşim açısından uygunsuz alanların akarsu vadileri çevresi ve fay hatlarına yakın sahalar olduğu tespit edilmiştir. Benzer bir tespit Türkiye ölçeğinde Bolu'da CBS'ye dayalı bir modelle gerçekleştirilen diğer başka bir çalışmada yapılmıştır (Alparslan vd., 2008: 134).

$\mathrm{Bu}$ çalışma, CBS destekli kentsel modelleme çalışmalarının yerleşime uygunluk analizlerinde kullanılabileceğini göstermiştir. Benzer sonuçlar Bolu (Alparslan vd., 2008: 139) ve Kocaeli (Aydöner ve Maktav, 2013: 62) için de geçerlidir. Bilhassa Aydöner ve Maktav (2013) CBS destekli yöntemlerin Türkiye'de kullanımının, planlama faaliyetlerinde isabetli olduğunu ve doğru kararların alınması açısından, gerek merkezi yönetim, gerekse yerel yönetimler bazında yaygınlaştırılmasının yararlı olacağını bildirmişlerdir (Aydöner ve Maktav, 2013: 62). Park vd. (2011) Güney Kore örneğinde kentsel sürdürülebilir arazi indeksinin analiz sonuçlarına göre CBS'ye dayalı yaklaşımlarla kentsel planlama açısından çok yararlı veriler üretildiğine dikkat çekmişlerdir (Park vd., 2011: 112).

Çalışmamızda kentsel çevrenin doğal çevre bileşenlerinin planlama yönünden değerlendirilmesinin planlama açısından kullanılabilir sonuçlar verdiği anlaşılmıştır. Keza Dai vd. (2001) tarafından CBS kullanılarak Çin'in Lanzhou kenti için yapılan çalışmada CBS'ye dayalı gerçekleştirilen analizlerin doğal çevre bileşenlerinin değerlendirilmesi bakımından yararlı olduğu ve planlama açısından uygun sonuçlar verdiği açıklanmıştır (Dai et al., 2001: 270). Uy ve Nakagoshi (2008) tarafından CBS teknikleri ve AHS yöntemiyle yapılan kentsel çevre sürdürülebilirlik analiz sonuçlarıyla da sürdürülebilir kentsel ortamın oluşturulabilmesi için doğal çevre bileşenlerini dikkate alan çalışmaların yapılması gerekliliği vurgulanmıştır (Uy ve Nakagoshi, 2008: 38).

CBS tabanlı uygulamalarda çok sık bir şekilde kullanılan çok kriterli karar verme yöntemlerinden biri olan AHS kullanılarak Antakya kentinde doğal çevre bileşenlerinin analiz edildiği bu çalışma sonunda, Antakya şehrinin yarısından fazlasının yerleşmeye az uygun olduğu tespit edilmiştir. Yerleşmeye uygunsuz alanlar başta Asi Nehri olmak üzere akarsu vadileri ile fay hatlarına yakın konumda bulunan sahalardır. Şehrinin yakın gelecekte genişleyeceği mücavir alan sınırları içerisinde bazı riskli alanlar bulunmasına rağmen, şehrin en güvenilir alanları bu bölgededir. Bütün bu anlatılanlara dayanılarak şu öneriler geliştirilebilir;

1) Öncelikle gerek hâlihazırdaki kent alanı, gerekse mücavir alan sınırları dikkate alınarak doğal çevre bileşenlerinin de göz önünde bulundurulduğu daha detaylı planlamalar yapılmalıdır.

2) Daha sonra benzer planlama şehrin çevresindeki suburbanizasyon (banliyöleşme) alanı dahilinde genişletilmelidir.

3) Yapılacak planlamalarda CBS tekniklerine dayalı çeşitli yöntemlerden istifade edilmelidir.

4) Kent planlamasında çok farklı disiplinlerden bilim insanlarının katkıları, görüş ve önerileri de alınmalıdır. 
CBS ve AHS Kullanılarak Doğal Çevre Bileşenleri Açısından Kentsel Mekânın Yerleşime Uygunluk Analizine Bir Örnek: Antakya (Hatay)

5) Kent insanının konu hakkında görüşleri alınmalı ve işbirlikçi bir yaklaşım izlenmelidir.

6) Bilhassa kentsel dönüşüm aşamasında yukarıda sayılanlar mutlaka göz önünde tutulmalıdır.

Sonuç olarak, kentsel mekânın planlanmasında doğal çevre bileşenlerin çok önemli olduğu anlaşılmıştır. Kentlerin sürdürülebilir bakımından planlanması için doğal çevre bileşenlerini dikkate alan çalışmaların yapılmasına ihtiyaç vardır. Bu tarz çalışmalarda CBS'ye dayalı yöntemlerin kullanılması sağlıklı ve kullanılabilir sonuçlar üretilmesi bakımından oldukça mühimdir. Bu yöntemlerin benzer alanlarda da uygulanabilir olması bakımından tercih edilebileceği anlaşılmıştır.

\section{KAYNAKCA}

Akdeniz, H. A., Turgutlu, T., 2007, Türkiye'de Perakende Sektöründe Analitik Hiyerarşik Süreç Yaklaşımıyla Tedarikçi Performans Değerlendirilmesi, Dokuz Eylül Üniversitesi Sosyal Bilimler Enstitüsü Dergisi, Cilt: 9, Sayı: 1,s.: 1-17.

Aktaş, R., Kısa T., Doğanay, M., Tarım, A., 2001, Karar Analizleri, KHO Basımevi, Ankara. Aliağaoğlu, A., Uğur, A., 2010, Şehir Coğrafyası, Nobel Yayın Dağıtım, Ankara.

Alparslan, E., Ince, F., Erkan, B., Aydöner, C., Özen, H., Dönertaş, A., Ergintav, S., Yağsan, F. S., Zateroğulları, A., Eroğlu, I., Değer, M., Elalmış, H., Özkan, M., 2008, A GIS model for settlement suitability regarding disaster mitigation, a case study in Bolu Turkey, Engineering Geology, Volume: 96, pp.: 126-140.

Angillieri, M. Y., 2010, Application of frequency ration and logistic regression to active rock glacier occurrence in the Andes of San Juan, Argentina, Geomorphology, Volume: 114, pp.: 396-405.

Antakya Belediyesi, 2006, 1. ve 2. Etap İmar Planına Esas Jeolojik Jeoteknik Etüt Raporu, Hendese Jeoteknik Mühendislik İmar İnşaat Sanayi Sanayi Ticaret Ltd.Şti, Ankara.

Ardel, A., Kurter, A., Dönmez, Y., 1969, Klimatoloji Tatbikat1, İstanbul Üniversitesi Yayınları, İstanbul.

Arslan, E. T., 2010, Analitik Hiyerarşi Süreci Yöntemiyle Strateji Seçimi: Süleyman Demirel Üniversitesi İktisadi ve İdari Bilimler Fakültesinde Bir Uygulama, Süleyman Demirel Üniversitesi İktisadi ve İdari Bilimler Fakültesi Dergisi, Cilt: 15, Sayı: 2, s.: $455-477$.

Atalay, İ., 1994, Türkiye Vejetasyon Coğrafyası, Ege Üniversitesi Basımevi, İzmir.

Ateş, Ş., Keçer, M., Osmançelebioğlu, R., Kahraman, S., 2004, Antakya (Hatay) İl Merkezi ve Çevresinin Yerbilim Verileri, MTA. Enstitüsü Jeoloji Etütleri Dairesi Derleme Raporu No: 10717, Ankara.

Aydın, O., 2011, CBS Temelli Hücresel Otomata Yöntemiyle Kentsel Büyüme Modeli: Ankara Örneği, Coğrafi Bilimler Dergisi, Sayı: 9 (2), s.: 135-157. 
The Analysis of Habitability of Urban Spaces In Terms of Natural Environmental Components By Means of GIS and AHP: The Case of Antakya (Hatay)

Aydöner, C., Maktav, D., 2013, Deprem Açısından Yerleşim Yeri Uygunluk Analizleri, Havacılık ve Uzay Teknolojileri Dergisi, Cilt: 6, Sayı: 1, s.: 53-62.

Baer, K. E., Pringle, C. M., 2000, Special problems of urban river conservation: the encroaching megalopolis. In Global Perspectives on River Conservation: Science, Policy, and Practice (Edit.: Boon, P. J., Davies, B. R., Petts, G. E.), pp.: 385-402, Wiley, New York.

Bayar, R., 2005, CBS Yardımıyla Modern Alışveriş Merkezleri İçin Uygun Yer Seçimi: Ankara Örneği, Coğrafi Bilimler Dergisi, Sayı: 3 (2), s.: 19-38.

Berry, B. J. L., 1990, Urbanization, Chapter: 7, The Earth as Transformed by Human action, Global and Regional Changes in the Biospher Over the Past 300 Years, Edited by B. L. Turner II, William C. Clark, Robert W. Kates, John F. Richards, Jessica T. Mathews, William B. Meyer, USA: Cambridge University Press.

Bilgin, A., 1989, Yerleşme alanlarının seçiminde jeomorfoloji, Jeomorfoloji Dergisi, Sayı: 17, s.: $35-43$.

Brown, L. R., Gray, R. H., Hughes, R. M., Meador, M. R., 2005, Introduction to Effects of Urbanization on Stream Ecosystems, 2005 by the American Fisheries Society, American Fisheries Society Symposium, Volume: 47, pp.: 1-8.

Bulut, Y., Korkmaz, H., 2008, 5893 Sayılı Belediye Yasası Çerçevesinde Antakya Kentsel Alanının İrdelenmesi, Dönüşen Kentler ve Değişen Yerel Yönetimler (Edit.: Genç, N. F., Yılmaz, A., Özgür, H.), Gazi Kitabevi, Ankara.

Butler, D., Davies, J. W., 2000, Urban Drainage, E \& FN Spon, New York.

Byun, D. H., 2001, The AHS Approach For Selecting an Automobile Purchase Model, Information \& Management, Volume: 38, pp.: 289-297.

Cürebal, İ., 2004, Yer Değiştiren Yerleşmelere İki Örnek: Kıratlı ve Bahçeli Köyleri, İstanbul Üniversitesi Edebiyat Fakültesi Coğrafya Bölümü Coğrafya Dergisi, Sayı: 12, s.: 75-84.

Çetin, B., 2010, Antakya (Hatay) Nüfusunun 1940-2008 Yılları Arasındaki Gelişimi ve Temel Özellikleri, Hatay Araştırmaları I, Antakya Belediyesi, Pegem Yayınları, s: $179-225$.

Çetin, B., 2012a, Hatay'da Kentleşmenin Seyri (1940-2009) ve Mekânsal Dağılışı, Doğu Coğrafya Dergisi, Sayı: 28, s.: 231-258.

Çetin, B., 2012b, Antakya ve İskenderun-Dörtyol Çevresinde Suburbanizasyon (Banliyöleşme), Doğu Coğrafya Dergisi, Sayı: 28, s.: 259-282.

Dağdeviren, M., Eren, T., 2001, Tedarikçi Firma Seçiminde Analitik Hiyerarşi Prosesi ve 01 Hedef Programlama Yöntemlerinin Kullanılması, Gazi Üniversitesi MühendislikMimarlık Fakültesi Dergisi, Sayı: 16 (2), s.: 41-52. 
CBS ve AHS Kullanılarak Doğal Çevre Bileşenleri Açısından Kentsel Mekânın Yerleşime Uygunluk Analizine Bir Örnek: Antakya (Hatay)

Dai, F. C., Lee, C. F., Zhang, X. H., 2001, GIS-based geo-environmental evalution for urban land-use planning: a case study, Engineering Geology, Volume: 61, pp.: 257-271.

Değerliyurt, M., 2013, Antakya'da Doğal Afet Risk Analizi ve Yönetimi, Doktora Tezi, İstanbul Üniversitesi Sosyal Bilimleri Enstitüsü, İstanbul.

Demirtaş, R., 2003, Yerleşim ve yapı güvenliği açısından diri faylardan ne kadar uzaklaşılmalı?, (Antakya ve Osmaniye depremselliği ve kentleşmeye etkileri), TMMOB. 26-27 Haziran 2003, Konferanslar Serisi: 1, Jeoloji Odası Yayınları, No: 76, s.: 46-67, Ankara.

Demographia, 2012, Demographia World Urban Areas, 8th Annual Edition: Version 2,Demographia and The Public Purpose, Belleville, USA.

Döker, M. F., 2012, İstanbul Kentsel Büyüme Sürecinin Belirlenmesi, İzlenmesi ve Modellenmesi, Doktora Tezi, İstanbul Üniversitesi Sosyal Bilimler Enstitüsü Coğrafya Anabilim Dalı, İstanbul.

Dönmez, Y., 1979, Umumi Klimatoloji ve İklim Çalışmaları, İstanbul Üniversitesi Edebiyat Fakültesi Yayınları No: 2506, İstanbul.

Duda, A. M., Lenat, D. R., Penrose, D. L., 1982, Water quality in urban streams-what we can expect, Journal Water Polluttion Control Federation, Volume: 54, pp.: 1139-1147.

Dündar, S., Ecer, F., 2008, Öğrencilerin GSM Operatörü Tercihinin Analitik Hiyerarşi Süreci Yöntemiyle Belirlenmesi, Celal Bayar Üniversitesi İ.İ.B.F. Yönetim ve Ekonomi Dergisi, Cilt: 15, Sayı: 1, s.: 195-205.

Ellis, J. B., Marsalek, J., 1996, Overview of urban drainage: environmental impacts and concerns, means of mitigation and implementation policies. Journal of Hydraulic Research, Volume: 34, pp.: 723-731.

Erdem, M., Serdar Kaya, H., 2013, İstanbul'un Dere ve Nehirlerinin Ekolojik Tasarım Yaklaşımları Doğrultusunda İrdelenmesi, Coğrafyacılar Derneği Yıllık Kongresi Bildiriler Kitabı, s.: 390-398, 19-21 Haziran 2013, Fatih Üniversitesi, İstanbul.

Erkal, T., Taş, B., 2013, Jeomorfoloji ve İnsan (Uygulamalı Jeomorfoloji), Yeditepe Yayınevi, İstanbul.

Erol, O., 2004, Genel Klimatoloji, 6. Baskı, Çantay Kitabevi, İstanbul.

Girgin, M., 1995, Kütle Hareketleri Nedeniyle Yeri Değiştirilen Yerleşmelere Bir Örnek, Doğu Coğrafya Dergisi, Sayı: 1, s.: 155-170.

Heaney, J. P., Huber, W. C., 1984, Nationwide assessment of urban runoff on receiving water quality, Water Resources Bulletin, Volume: 20, pp.: 35-42.

Herece, E., 2008, Doğu Anadolu Fayı (DAF) Atlası, Maden Tetkik ve Arama Genel Müdürlüğü, Ankara. 
The Analysis of Habitability of Urban Spaces In Terms of Natural Environmental Components By Means of GIS and AHP: The Case of Antakya (Hatay)

House, M. A., Ellise, J. B., Herricks, E. E., Huitved-Jacobsen, T., Seager, J., Lijklema, L., Aalderink, H., Clifforde, I. T., 1993, Urban drainage-impacts on receiving water quality. Water science \& technology, Volume: 27, pp.: 117-58.

Hynes, H. B. N., 1960, The Biology of Polluted Waters, Liverpool University Press, Liverpool, UK.

Kılıç, Ş., Ağca, N., Karanlık, S., Şenol, S., Aydın, M., Yalçın, M., Çelik, İ., Evrendilek, F., Uygur, V., Doğan, K., Aslan, S., Çullu, M. A., 2008, Amik Ovasının Detaylı Toprak Etütleri, Verimlilik Çalışması ve Arazi Kullanım Planlaması, Mustafa Kemal Üniversitesi Bilimsel Araştırma Projeleri, Proje No: DPT2002K120480, Antakya/Hatay.

Klein, R. D., 1979, Urbanization and stream quality impairment, Water Resources Bulletin, Volume: 15, pp.: 948-963.

Korkmaz, H., 2006, Antakya'da Zemin Özellikleri ve Deprem Etkisi Arasındaki İlişki, Ankara Üniversitesi Türkiye Coğrafya Araştırma ve Uygulama Merkezi Coğrafi Bilimler Dergisi, Sayı: 4 (2), s.: 47-63.

Korkmaz, H., 2007, Kuruşundan Günümüze Antakya'da Su, Frat Üniversitesi Sosyal Bilimler Dergisi, Sayı: 17/1, s.: 69-96.

Korkmaz, H., Fakı, G., 2009, Kuseyr Platosu'nun İklim Özellikleri. Mustafa Kemal Üniversitesi Sosyal Bilimler Enstitüsü Dergisi, Cilt: 6, Sayı: 12, s.: 324-350.

Kwiesielewiczk, M., Uden, E. V., 2004, Inconsistent and Contradictory Judgements In Pairwaise Comparison Method In The AHP, Computers \& Operations Research, Volume: 31, pp.: 713-719.

Lee, S., Ryu, J. H., Lee, M. J., Won, J. S., 2003, Use of an artificial neural network for analysis of the susceptibility to landslides at Boun, Korea, Environmental Geology, Volume: 44, pp.: 820-833.

Lee, S., Sambath, T., 2006, Landslide susceptibility mapping in the Damrei Romel area, Cambodia using frequency ratio and logistic regression models, Environmental Geology, Volume: 50, pp.: 847-855.

McBride, S. B., 1999, Site Planning and Design, Regional Research Institute, West Virginia University, http://rri.wvu.edu/WebBook/McBride/main.html, Son Erişim Tarihi: 10.12.2013.

Özdemir, M. A., 1996, Türkiye'de Büyük Yerleşme Alanlarının Seçiminde Jeomorfolojik Esaslar, Frrat Üniversitesi Sosyal Bilimler Dergisi, Sayı: 8 (2), s.: 209-222.

Özşahin E., Değerliyurt M. 2013, Modeling of Seismic Hazard Risk Analysis in Antakya (Hatay, South Turkey) by Using GIS, International Journal of Innovative Environmental Studies Research, Volume: 1 (3), pp.: 31-54.

Özşahin E., Kaymaz Ç. K., 2013a, Antakya ve Erzurum Kentlerinin Jeomorfolojik Özelliklerinin Kentsel Ekoloji Penceresinden Analizi, Kuramdan Uygulamaya 
CBS ve AHS Kullanılarak Doğal Çevre Bileşenleri Açısından Kentsel Mekânın Yerleşime Uygunluk Analizine Bir Örnek: Antakya (Hatay)

Yerel Yönetimler ve Kentsel Politikalar (Editörler: Yakup Bulut, Veysel Eren, Sedat Karakaya, Abdullah Aydın), s.: 779-788, Pegem Akademi, Ankara.

Özşahin, E., Kaymaz, Ç. K., 2013b, Taşkın Riskinin Değerlendirmesine Bir Örnek: Amik Ovası Taşkınları, Turkish Studies-International Periodical For the Languages, Literature and History of Turkish or Turkic, Volume: 8/8, pp.: 2021-2039.

Özşahin, E., 2010, Antakya'da (Hatay) Yer Seçiminin Jeomorfolojik Özellikler ve Doğal Risk Açısından Değerlendirilmesi, Balıkesir Üniversitesi Sosyal Bilimler Enstitüsü Dergisi, Say1: 13/23, s.: 1-16.

Özşahin, E., 2012, Mekânın Fiziksel Planlanmasına Bir Örnek: Alan Yaylası (Kırıkhan/HATAY), Uluslararası Sosyal Araştırmalar Dergisi, Cilt: 5, Sayı: 23, s.: 373-385.

Özşahin, E., Özder, A., 2011, Antakya Şehri ve Jeomorfolojik Birimler Arasındaki İlişkinin Zamansal Değişimi (HATAY), Fiziki Coğrafya Araştırmaları; Sistematik ve Bölgesel, Türk Coğrafya Kurumu Yayınları, No: 5, s.: 657-680, İstanbul.

Pamir, H., 2009, Alalakh'dan Antiokheia’ya Hatay’da Kentleşme Süreci, Mustafa Kemal Üniversitesi Sosyal Bilimler Enstitüsü Dergisi, Sayı: 6 (12), s.: 258-288.

Park, S., Jeon, S., Kim, S., Choi, C., 2011, Prediction and comparison of urban growth by land suitability index mapping using GIS and RS in South Korea, Landspace and Urban Planning, Volume: 99, pp.: 104-114.

Paul, M. J., Meyer, J. L., 2001, Streams in the urban landscape, Annual Review of Ecological Systems, Volume: 32, pp.: 333-365.

Porcella, D. B., Sorensen, D. L., 1980, Characteristics of non-point source urban runoff and its effects on stream ecosystems, EPA-600/3-80-032, EPA, Washington, USA.

Saaty, T. L., 1986, Axiomatic Foundation of the Analytic Hierarchy Process, Management Science, Volue: 32 (7), pp.: 841-855.

Saaty, T. L., 1994, How to make a decision: the analytic hierarchy process, Interfaces, Volume: 24, pp.: 19-43.

Saaty, T. L., Vargas, L. G., 2001, Models, Methods, Concepts and Applications of the Analytic Hierarchy Process, Kluwer Academic Publishers, Boston.

Saaty, T. L., Vargas, L. G., Dellman, K., 2003, The Allocation of Instangible Resources: The Analytic Hierarchy Process and Linear Programming, Socio-Economic Planning Sciences, Volume: 37, pp.: 169-189.

Scholl, A., Manthey, L., Helm, R., Steiner, M., 2005, Solving Multiattribute Design Problems with Analytic Hierarchy Process and Conjoint Analysis: An Empirical Comparison, European Journal of Operational Research, Volume: 164, pp.: 760-777. 
The Analysis of Habitability of Urban Spaces In Terms of Natural Environmental Components By Means of GIS and AHP: The Case of Antakya (Hatay)

Shrestha, R. K., Alavalapatı, J. R. R., Kalmbacher, R. S., 2004, Exploring the Potential for Silvopasture Adoption in South-central Florida: an Application of SWOT-AHP Method, Agricultural Systems, Volume: 81, pp.: 185-199.

Soba, M., Bildik, T., 2013, İlçelerde Fakülte Yeri Seçiminin Analitik Hiyerarşi Süreci Metodu İle Belirlenmesi, KAU IIBF Dergisi, Sayı: 4 (5), s.: 51-63.

Suren, A. M., 2000, Effects of urbanisation, In New Zealand Stream Invertebrates: Ecology and Implications for Management (Edit.: Collier, K. J., Winterbourn, W. J.) pp.: 260-288. N.Z. Limnol. Soc., Hamilton.

Toksarı, M., 2007, Analitik Hiyerarşi Prosesi Yaklaşımı Kullanılarak Mobilya Sektörü için Ege Bölgesi'nde Hedef Pazarın Belirlenmesi, Celal Bayar Üniversitesi İ.̇̇.B.F. Yönetim ve Ekonomi Dergisi, Cilt: 14, Sayı: 1, s.: 171-180.

Tonbul, S., Sunkar, M., 2008, Batman Şehrinde Yer Seçiminin Jeomorfolojik Özellikler ve Doğal Risk Açısından Değerlendirilmesi, Ulusal Jeomorfoloji Sempozyumu Bildiriler Kitapçı̆̆ı (20-23 Ekim 2008), s.: 103-113, Çanakkale.

Topay, M., 2013, Mapping of thermal comfort for outdoor recreation planning using GIS: The case of Isparta Province (Turkey), Turkish Journal of Agriculture and Forestry, Volume: 37, pp.: 110-120.

TUIKK ADNKS (Adrese Dayalı Nüfus Kayıt Sistemi), 2010, Antakya kentinin mahalleleri 31.12.2010, TUİK, Ankara.

Uy, P. D., Nakagoshi, N., 2008, Application of land suitability analysis and landscape ecology to urban greenspace planning in Hanoi, Vietnam, Urban Forestry \& Urban Greening, Volume: 7, pp.: 25-40.

Wind, Y., Saaty, T. L., 1980, Marketing Applications of the Analytic Hierarchy Process, Management Science, Volume: 26 (7), pp.: 641- 658.

Yalçınlar, İ., 1967, Türkiye'de bazı şehirlerin kuruluş ve gelişmesinde jeomorfolojik temeller, İstanbul Üniversitesi Coğrafya Enstitüsü Dergisi, Sayı: 16, s.: 53-66. 
CBS ve AHS Kullanılarak Doğal Çevre Bileşenleri Açısından Kentsel Mekânın Yerleşime Uygunluk Analizine Bir Örnek: Antakya (Hatay) 